\title{
NEK2 Is an Effective Target for Cancer Therapy With Potential to Induce Regression of Multiple Human Malignancies
}

\author{
TOSHIO KOKURYO, YUKIHIRO YOKOYAMA, JUNPEI YAMAGUCHI, \\ NOBUYUKI TSUNODA, TOMOKI EBATA and MASATO NAGINO \\ Division of Surgical Oncology, Department of Surgery, \\ Nagoya University Graduate School of Medicine, Nagoya, Japan
}

\begin{abstract}
Cancer is characterized by uncontrolled cell proliferation due to the aberrant activity of various proteins. Cell cycle-related proteins are thought to be important in several functions, such as proliferation, invasion and drug resistance in human malignancies. Never in mitosis gene A-related kinase 2 (NEK2) is a cell cycle-related protein. NEK2 is highly expressed in various tumor types and cancer cell lines. NEK2 expression is correlated with rapid relapse and poor outcome in multiple cancer types. Several researchers have demonstrated that NEK2 inhibition results in anticancer effects against many types of cancers, both in vitro and in vivo. Recent research strongly indicates the advantages of NEK2-targeted therapy for cancer. This review focuses on the current understanding of NEK2 in cancer and the rationale of a xenograft cancer model for cancer treatment. A possible therapeutic strategy, such as inhibitor and nucleic acid medicine targeting of NEK2, is also discussed.
\end{abstract}

Cancer is characterized by uncontrolled cell proliferation due to the aberrant activity of various proteins (1). Recent studies have revealed that cell cycle-related proteins play important roles in multiple cancer types $(2,3)$. Many forms of cancers are uniquely dependent on these proteins and hence are selectively sensitive to their inhibition (1). In this regard, cellcycle regulators are effective targets for cancer treatment.

Never in mitosis gene A-related kinase 2 (NEK2) is a cell cycle-related protein, along with aurora kinases and

This article is freely accessible online.

Correspondence to: Toshio Kokuryo, Division of Surgical Oncology, Nagoya University Graduate School of Medicine, 65 Tsurumai-cho, Showa-ku, Nagoya 466-8550, Japan. Tel: +81 527442222, Fax: +81 527442230, e-mail: kokuryoh@med.nagoya-u.ac.jp

Key Words: Drug delivery system, Inhibitor, NEK2, nucleic acid medicine, xenograft cancer model, review. polo-like kinases $(4,5)$. Several studies have been published concerning the roles of NEK2 in chromosome instability, tumorigenesis, progression, and drug resistance in cancer (6-8).

This review focuses on the current understanding of NEK2 in cancer progression and the rationale of a xenograft cancer model for cancer treatment. A possible therapeutic strategy, such as inhibitor and nucleic acid medicine targeting of NEK2, is also discussed.

\section{Structure of NEK2}

NEK2 is structurally related to the mitotic regulator never in mitosis gene A (NIMA), which is cloned from Aspergillus nidulans (9). Eleven mammalian homologs of the NEK family, named NEK1 to NEK11, have been identified (5, 10). The NEK family comprises several serine/threonine kinases and is important for cell division and cell-cycle regulation, as well as NIMA (11). NEK2 is the closest mammalian isoform to NIMA and has structures with a serine-threonine kinase domain located at the aminoterminal and multiple regulatory motifs, such as a leucine zipper, coiled coil, centrosome and microtubule localization sites, protein phosphatase 1 (PP1) binding site, KEN-box, nucleolar localization sites, anaphase-promoting complex (APC) binding site, and destruction box (D-box) at the carboxyl-terminal site (12). NEK2 in mammals has three splice variants: NEK2A, NEK2B, and NEK2C $(13,14)$. NEK2A and NEK2B differ at their carboxy-termini $(15,16)$, and NEK2C lacks an eight-amino acid sequence from the carboxy-terminus of NEK2A (14). NEK2A is evenly distributed within the nuclei and cytoplasm, while NEK2B is mainly distributed in the cytoplasm, and NEK2C is mainly distributed in the nuclear region (14). As NEK2A, NEK2B and NEK2C exhibit overlapping or identical substrate usage, these variants are collectively referred to here as NEK2 (17-20). 


\section{NEK2 Expression in Cancer}

High expression of NEK2 was first identified in pediatric solid tumors called Ewing's sarcoma using microarray analysis (21). We reported that NEK2 is highly expressed in several cancer types, such as cholangiocarcinoma (22), breast $(7,23-31)$, colorectal $(27,32-35)$, and pancreatic $(36,37)$ cancer. Consistently, several researchers reported that high expression of NEK2 is identified in various cancer types, including testicular seminoma $(27,38,39)$, cervical tumor (27), primary liver cancer (40), hepatocellular carcinoma (8, $41)$, prostate cancer $(27,42)$, lung cancer $(27,43-45)$, ovarian cancer (46), renal cell cancer $(47,48)$, myeloma (49), peripheral nerve sheath tumors (50), follicular lymphoma $(51,52)$ and diffuse large B-cell lymphoma (52).

NEK2 overexpression is significantly associated with histological differentiation, higher in TNM stage, lymph node metastasis and tumor invasion in colon (33), pancreatic (37), and lung (43) cancer. NEK2 is a promising predictor of poor prognosis in cancer because its expression is highly correlated with rapid relapse and poor outcome in multiple cancer types.

\section{Functional Role of NEK2 in Cancer}

NEK2 expression is low in the $G_{1}$ phase of the cell cycle, increasing through $S$ and $G_{2}$ to reach a peak in late $G_{2} / M$, and decreasing upon cell entry into mitosis $(5,15)$. Similarly, NEK2 activity is stronger in the $S$ and $G_{2}$ phases compared to that in other phases. NEK2 is responsible for starting centrosome separation at the $\mathrm{G}_{2} / \mathrm{M}$ phase of the cell cycle (53). NEK2 overexpression results in chromosome instability and aneuploidy in cancer cells $(6,54,55)$. In addition, NEK2 overexpression activates several oncogenic pathways and ATP-binding cassette transporters, thereby leading to cell proliferation, invasion, and drug resistance (55).

Proliferation. We demonstrated that increased NEK2 promoted cell growth and NEK2-targeting siRNA inhibited proliferation in cholangiocarcinoma (22). NEK2 siRNA suppressed tumor growth in a xenograft nude mouse model (22). Another group also demonstrated that increased expression of NEK2 promoted cell proliferation, while its suppression inhibited proliferation in various cancer types $(24,28,31,42,54)$. Zhou et al. reported that both the PP1/AKT and the WNT signaling pathways may be involved in NEK2-induced cell proliferation (54). Several studies revealed that NEK2 expression is strongly related to $\mathrm{Ki}-67$, a proliferation marker, in various malignancies $(31,44,54)$. These data indicate the critical roles of NEK2 in cancer proliferation, both in vitro and in vivo.

Invasion and motility. Invasiveness and motility are associated with various genes in many cancer types (56-58).
Hayward et al. first reported that NEK2 overexpression preceded metastasis in cancer cells (24). We previously reported that NEK2 expression affected invasion and motility in breast cancer and pancreatic cancer cells $(23,36)$. Xia et al. reported that NEK2 played an important role in tumor metastasis by regulating the expression and localization of $\beta$-catenin, because NEK2 overexpression induced nuclear accumulation of $\beta$-catenin in multiple myeloma and lung cancer cells (55). NEK2 induced metastasis in cooperation with RAS and SRC signaling and promoted chromosomal instability in cancer (59). From these data, NEK2 is believed to be involved in invasion and motility and to promote metastasis in cancer.

Apoptosis. The inactivation of apoptosis is central to cancer progression. Apoptosis is involved in the resistance to therapy of many kinds of cancer.

NEK2 depletion leads to aneuploidy and cell-cycle arrest; thereafter, apoptosis was found to be induced as a result of mitotic errors in various cancer cell lines $(19,27,28,54)$. Naro et al. reported that NEK2 inhibition in cancer cells led to high expression of cleaved PARP and activated caspase3 , caspase- 8 , and caspase- 9 in vitro and in a xenograft mouse model of myeloma $(27,54)$. These data indicate an important role of NEK2 against the apoptosis pathway. However, Lee and Gollahon reported that NEK2 suppression did not induce strong mitotic arrest in the $\mathrm{G}_{2} / \mathrm{M}$ phase, but instead induced apoptosis. This indicates that the role of NEK2 may be different from other cell cycle-related kinases in regulation of cell cycle (60). The mechanisms concerning apoptosis by NEK2 suppression remain unclear in cancer cells.

Drug sensitivity and resistance. Drug sensitivity and resistance are important issues in cancer treatment. Developing a novel strategy for enhancement of sensitivity to chemotherapeutic agents is one of the most serious challenges in improving the prognosis of patients with cancer. NEK2 was shown to regulate chemotherapeutic resistance through several genes, such as ATP binding cassette subfamily $\mathrm{G}(A B C G)$, aldehyde dehydrogenase 1 family, member A1 (ALDH1A1), and Retinoid X receptor alpha $(R X R A)$ in malignancies $(8,61)$. NEK2 overexpression is associated with drug-resistant ovarian cancer and multiple myeloma $(46,62)$. Some researchers reported NEK2 to be involved in resistance to 5-fluorouracil, tamoxifen, trastuzumab, paclitaxel and doxorubicin (7, 60, 63). Therefore, NEK2 appears to contribute to resistance to several drugs in multiple cancer types.

Drug efflux plays an essential role in increasing drug resistance in a variety of malignancies. NEK2 depletion reduced drug efflux pump activity and inhibited drug resistance (61). NEK2 inhibition might be a therapeutic option for treating chemoresistant cancer cells. 
We previously reported that the combination of $N E K 2$ siRNA and cisplatin showed additive antitumor effects on colorectal cancer cells (32). siRNA and antisense oligonucleotide against NEK2 worked synergistically with paclitaxel and doxorubicin by promoting apoptosis of breast cancer cells (60). NEK2 combined treatment would be useful to abrogate the resistance to chemotherapy and further improve clinical outcomes.

\section{Therapeutic Potential of NEK2 in a Xenograft Cancer Model}

The studies using various cancer cell lines suggest that the inhibition of NEK2 may be beneficial for cancer treatment. Even if agents are effective against cell lines, they often demonstrate no efficacy in xenograft model. In this regard, it is important to confirm the therapeutic potential of NEK2 for cancer treatment in several xenograft cancer models, such as subcutaneous tumors, peritoneal dissemination and liver metastasis. Several researchers reported the efficiency of NEK2 inhibition in various xenograft cancer models.

Subcutaneous tumors. We reported that NEK2 silencing suppressed xenograft tumor growth of cholangiocarcinoma (22), and breast (23), colorectal (32), and pancreatic (36) cancer. In addition, NEK 2 inhibition showed efficiency in other xenograft cancer models, such as myeloma, and prostate, liver, colorectal, and breast $(42,54,64-66)$ cancer.

Peritoneal dissemination. Peritoneal dissemination is a major undesirable complication frequently associated with inoperable cases of cancer. Many patients with cancer die of peritoneal dissemination because of lack of effective and useful treatment. NEK2 overexpression is associated with serosal invasion, lymphatic invasion, and peritoneal dissemination (34).

We previously reported that NEK2 siRNA improves the survival of nude mice with peritoneal dissemination of cholangiocarcinoma (22) and pancreatic cancer (36) xenografts. The total nodule number and weight of peritoneal dissemination in the NEK2 siRNA-treated group were significantly lower than those in the control siRNA-treated group.

Liver metastasis. Multiple metastases are considered to be detrimental to the outcome of cancer because it is impossible to remove all lesions during an operation. Although NEK2 is highly expressed in liver metastases, the significance of NEK2 expression using xenografts has not been investigated.

We previously examined the potential of NEK2 siRNA for metastasis of pancreatic cancer (36). NEK2 siRNA reduced the number and the area of liver metastases from pancreatic cancer in a rat xenograft model (36). NEK2 siRNA was able to prevent the progression of liver metastasis efficiently.

\section{NEK2-targeted Cancer Therapy}

Despite the development of chemotherapy for cancer, clinical outcomes have not been markedly improved in many types of cancer. Novel strategies are therefore required to treat cancer, especially in the case of local recurrence, peritoneal dissemination and liver metastasis. As NEK2 has a critical role in the progression of malignancies, as mentioned previously, it is attractive as a target for novel anticancer therapies $(55,67)$.

NEK2 inhibitors. Several small-molecule inhibitors of NEK2 were developed in high-throughput screening (68) (Table I). These inhibitors showed their therapeutic effectiveness against cancer cells both in vitro and in vivo.

Propynamide16 was designed as an irreversible, cysteinetargeted inhibitor of NEK2 through a structure-based approach. This compound inhibited cellular NEK2 without affecting the mitotic kinases, cyclin-dependent kinase 1 (CDK1), aurora B, or polo-like kinase 1 (PLK1). This compound was the first small molecule shown to inactivate NEK2 kinase activity in cells (69).

Highly expressed in cancer 1 (HEC1) is a critical mitotic regulator, which is phosphorylated by NEK2 in proper chromosome segregation (70). TAI-95 and TAI-1, small molecules targeting the HEC1/NEK2 pathway, inhibited tumor growth in xenograft mouse models of liver, colorectal , and breast cancer $(60,64-66)$. A 4-aryl-N-arylcarbonyl-2aminothiazole was designed and synthesized as an HEC1/ NEK2 inhibitor. This compound also demonstrated inhibition of tumor growth in a xenograft breast cancer model (71).

A small molecule, $N$-(4-[2,4-dimethyl-phenyl]-thiazol-2yl)-benzamide (INH1), specifically disrupted HEC1/NEK2 interaction via direct HEC1 binding. This INH-bound HEC1 triggered NEK2 degradation and eventually induced cell death. INH1 effectively inhibited the proliferation of breast cancer cell lines $(72,73)$. Several INH derivatives were designed and synthesized, which significantly suppressed xenograft tumor growth without obvious toxicity (74).

The epidermal growth factor receptor /human epidermal growth factor receptor 2 (EGFR/HER2) inhibitors neratinib and pelitinib also inhibited human NEK2 activity in vitro (59). Aminopyridine (R)-21, a potent and selective inhibitor based on an aminopyridine scaffold, modulated NEK2 activity in cells (75). Two viridian-like compounds, CC004731 and CC004733, suppressed NEK2 activity and inhibited the proliferation of human cancer cell lines (76). HCI-2389 was designed as a NEK2 inhibitor by virtual screening, and successfully mitigated drug resistance in bortezomib-resistant multiple myeloma (62).

Nucleic acid medicine. Several studies demonstrated that NEK2 inhibition using nucleic acids such as siRNA, 
Table I. Inhibitory effect of never in mitosis gene A-related kinase 2 (NEK2) inhibitors in subcutaneous xenograft animal models.

\begin{tabular}{|c|c|c|c|c|c|c|c|}
\hline Cancer type & Cell line & Animal & Agent & Dose, $\mathrm{mg} / \mathrm{kg}$ & & $\begin{array}{l}\text { Administration } \\
\text { method and DDS }\end{array}$ & Ref \\
\hline Breast & MDA-MB-231 & CB.17, SCID mouse & TAI-1 & $\begin{array}{c}20 \\
150\end{array}$ & $\begin{array}{l}\text { i.v. } \\
\text { p.o. }\end{array}$ & $\begin{array}{l}2 / \mathrm{d} \times 28 \mathrm{~d} \\
2 / \mathrm{d} \times 28 \mathrm{~d}\end{array}$ & $(66)$ \\
\hline Colorectal & Colo-205 & CB.17, SCID mouse & TAI-1 & $7.5,22.5,50 \rightarrow 75$ & p.o. & $2 / \mathrm{d} \times 28 \mathrm{~d}$ & (66) \\
\hline Liver & Huh-7 & CB.17, SCID mouse & TAI-1 & $7.5,22.5,50 \rightarrow 75$ & p.o. & $2 / \mathrm{d} \times 28 \mathrm{~d}$ & (66) \\
\hline Liver & Huh-7 & CB.17, SCID mouse & TAI-95 & $1,2.5,10$ & p.o. & $2 / \mathrm{d} \times 28 \mathrm{~d}$ & (64) \\
\hline Breast & MDA-MB-231 & CB.17, SCID mouse & TAI-95 & 10,25 & p.o. & $2 / \mathrm{d} \times 28 \mathrm{~d}$ & (65) \\
\hline Breast & BT474 & CB.17, SCID mouse & TAI-95 & $10,25,50$ & p.o. & $2 / \mathrm{d} \times 28 \mathrm{~d}$ & (65) \\
\hline Breast & MCF7 & $\mathrm{Balb} / \mathrm{c}$, nude mouse & TAI-95 & $10,25,50$ & i.v. & $2 / \mathrm{d} \times 28 \mathrm{~d}$ & $(65)$ \\
\hline Breast & MDA-MB-231 & $\mathrm{Balb} / \mathrm{c}$, nude mouse & Compound 32 & $\begin{array}{c}20 \\
150\end{array}$ & $\begin{array}{l}\text { i.v. } \\
\text { p.o. }\end{array}$ & $\begin{array}{l}1 / \mathrm{d} \times 28 \mathrm{~d} \\
2 / \mathrm{d} \times 28 \mathrm{~d}\end{array}$ & (71) \\
\hline Breast & MDA-MB-468 & Balb/c, nude mouse & INH1 & 50,100 & i.v. & $\begin{array}{l}\text { Every other day } \times 7 \mathrm{w} \\
\quad(25 \text { cycles })\end{array}$ & (73) \\
\hline Breast & MDA-MB-468 & Balb/c, nude mouse & INH41 & 10,50 & i.p. & $3 / w \times 7 w$ & (74) \\
\hline Breast & MDA-MB-468 & Balb/c, nude mouse & INH154 & 5,20 & i.p. & $3 / w \times 7 w$ & (74) \\
\hline
\end{tabular}

i.s.: Local administration; i.p.: intraperitoneal; i.v.: intravenous; p.o.: oral; w: week; d: day; DDS: Drug Delivery System.

Table II. Inhibitory effect of nucleic acid medicine targeting never in mitosis gene A-related kinase 2 (NEK2) in xenograft animal models.

\begin{tabular}{|c|c|c|c|c|c|c|c|c|c|}
\hline Cancer type & Cell lines & Animal & Xenograft & $\begin{array}{l}\text { siRNA } \\
\text { for Nek2 }\end{array}$ & $\begin{array}{l}\text { Conc. } \\
\text { Vol. }\end{array}$ & & $\begin{array}{l}\text { Administration } \\
\text { ethod and DD }\end{array}$ & & Ref \\
\hline Cholangiocarcinoma & HuCCT1 & Balb/c nude mouse & Subcutaneous & siRNA & $20 \mu \mathrm{M}, 100 \mu \mathrm{l}$ & i.s. & Biocollagen & $1 / w \times 3 d$ & (22) \\
\hline Breast & $\begin{array}{l}\text { MDA- } \\
\text { MB-231 }\end{array}$ & Balb/c nude mouse & Subcutaneous & siRNA & $20 \mu \mathrm{M}, 100 \mu \mathrm{l}$ & i.s. & Biocollagen & $1 / w \times 3 d$ & (23) \\
\hline Breast & MCF7 & Balb/c nude mouse & Subcutaneous & siRNA & $20 \mu \mathrm{M}, 100 \mu \mathrm{l}$ & i.s. & Biocollagen & $1 / w \times 3 d$ & (23) \\
\hline Colorectal & DLD1 & Balb/c nude mouse & Subcutaneous & siRNA & $20 \mu \mathrm{M}, 100 \mu \mathrm{l}$ & i.s. & Biocollagen & $2 \mathrm{w} \times 3 \mathrm{~d}$ & (32) \\
\hline Colorectal & DLD1 & Balb/c nude mouse & Subcutaneous & $\begin{array}{l}\text { siRNA } \\
\text { (CDDP) }\end{array}$ & $\begin{array}{c}50 \mu \mathrm{M}, 100 \mu \mathrm{l} \\
(4 \mathrm{mg} / \mathrm{kg})\end{array}$ & $\begin{array}{l}\text { i.s. } \\
\text { i.p. }\end{array}$ & $\begin{array}{c}\text { Biocollagen } \\
-\end{array}$ & $\begin{array}{l}2 / w \times 2 w \\
(2 / w \times 2 w)\end{array}$ & (32) \\
\hline Pancreas & KLM1 & Balb/c nude mouse & Subcutaneous & siRNA & $50 \mu \mathrm{M}, 100 \mu \mathrm{l}$ & i.s. & Biocollagen & $1 / w \times 3 d$ & (36) \\
\hline Cholangiocarcinoma & HuCCT1 & Balb/c nude mouse & Peritoneal & siRNA & $20 \mu \mathrm{M}, 100 \mu \mathrm{l}$ & i.p. & Liposome & $1 / w \times 3 d$ & (22) \\
\hline Pancreas & KLM1 & Balb/c nude mouse & Peritoneal & siRNA & $50 \mu \mathrm{M}, 100 \mu \mathrm{l}$ & i.p. & Liposome & $1 / w \times 3 d$ & (36) \\
\hline Pancreas & KLM1 & F344/njcl rat & Liver metastasis & siRNA & $50 \mu \mathrm{M}, 100 \mu \mathrm{l}$ & i.v. & Liposome & $1 / \mathrm{d} \times 5 \mathrm{~d}$ & (36) \\
\hline Myeloma & APR1 & Nod-Rag/null mouse & Subcutaneous & $\begin{array}{l}\text { Nek2 silenced } \\
\text { cell using } \\
\text { shRNA }\end{array}$ & & i.s. & - & - & (54) \\
\hline Prostate & LNCAP & Balb/c nude mouse & Subcutaneous & $\begin{array}{l}\text { Nek2 silenced } \\
\text { cell using } \\
\text { siRNA }\end{array}$ & & i.s. & - & - & (42) \\
\hline
\end{tabular}

i.s.: Local administration; i.p.: intraperitoneal; i.v.: itravenous; p.o.: oral; w: week; d: day; CDDP: cisplatin; DDS: drug-delivery system.

antisense and miRNA may be beneficial for cancer therapy $(34,60,77)$ (Table II). Nucleic acid medicine is positioned to be a promising therapy. For instance, NEK2-targeting siRNA reduced the viability and proliferation of several cancers, including cholangiocarcinoma (22), breast (23), colorectal (32), and pancreatic (36). miR-128 suppressed NEK2 expression in cancer cells and thereafter inhibited cell proliferation and induced cell-cycle arrest (34).

Although siRNA is a beneficial tool for inhibiting the expression of a specific gene through a drug delivery system, an in vivo delivery system is especially important for clinical application. Mowa et al. reported that viral vectors such as adenoviral vectors and retroviral vectors were good systems for drug delivery of siRNA (78). However, viral vectors carry a risk of severe side-effects in clinical use.

We used biocollagen and liposome as delivery carriers for NEK2 siRNA in a xenograft mouse model, such as subcutaneous tumor, peritoneal dissemination and liver metastasis $(22,23,32,36)$. Both delivery carriers were efficient in the transfection rate and for the effect of $N E K 2$ 
siRNA in cancer cells (36). Therefore, biocollagen and liposomes have advantages for clinical application as delivery carriers for nucleic acid medicine, including siRNA.

In addition, we have focused on the venous port-catheter system as another drug-delivery system for siRNA for liver metastasis. The system has already been applied in the clinic, and is effective as a drug delivery system for siRNA, because anticancer drugs are administered directly into tumors (36).

Further investigations are required in terms of safety and side-effects of the use of $N E K 2$ siRNA. We consider it possible that NEK2 siRNA will be a novel therapeutic strategy for the treatment of cancer.

\section{Future Perspectives}

Several researchers have demonstrated that the suppression of NEK2 results in inhibitory effects in many cancer types both in vitro and in vivo. Current research strongly indicates an advantage for NEK2-targeted cancer therapy. However, several crucial problems remain to be resolved. For instance, the signaling pathway of NEK2 in cancer may be partly shared by normal cells. We did not identify this complication related to NEK2 inhibition in several xenograft mouse models. However, the side-effects in NEK2-targeting therapy are difficult to predict completely. Further investigation of the role of NEK2 in cancer cells is thus crucial to prevent damage to normal cells. Taken together, these findings suggest that NEK2 is an effective target for cancer therapy and has the potential to promote the regression of multiple human malignancies.

\section{Conflicts of Interest}

The Authors have no conflicts of interest in regard to this study.

\section{Authors' Contributions}

In regard to our own work cited here, Toshio Kokuryo, Yukihiro Yokoyama and Masato Nagino conceived and planned experiments; Junpei Yamaguchi and Nobuyuki Tsunoda carried out experiments; Tomoki Ebata contributed to sample preparation and the interpretation of results. Toshio Kokuryo took the lead in writing the article. All Authors provided critical feedback and helped shape the research, analysis and article preparation.

\section{References}

1 Otto T and Sicinski P: Cell cycle proteins as promising targets in cancer therapy. Nat Rev Cancer 17: 93-115, 2017. PMID: 5345933. DOI: $10.1038 / \mathrm{nrc} .2016 .138$

2 Farley J, Ozbun L, Samimi G and Birrer MJ: Cell cycle and related protein. Dis Markers 23: 433-443, 2007. PMID: 3850569.

3 Kollmann K, Heller G, Schneckenleithner C, Warsch W, Scheicher R, Ott RG, Schafer M, Fajmann S, Schlederer M,
Schiefer AI, Reichart U, Mayerhofer M, Hoeller C, ZochbauerMuller S, Kerjaschki D, Bock C, Kenner L, Hoefler G, Freissmuth M, Green AR, Moriggl R, Busslinger M, Malumbres $M$ and Sexl V: A kinase-independent function of CDK6 links the cell cycle to tumor angiogenesis. Cancer Cell 24: 167-181, 2013. PMID: 3743049. DOI: 10.1016/j.ccr.2013.07.012

4 Lee MY, Moreno CS and Saavedra HI: E2F activators signal and maintain centrosome amplification in breast cancer cells. Mol Cell Biol 34: 2581-2599, 2014. PMID: 4097658. DOI: 10.1128/MCB.01688-13

5 Fry AM, O'Regan L, Sabir SR and Bayliss R: Cell cycle regulation by the NEK family of protein kinases. J Cell Sci 125 : 4423-4433, 2012. PMID: 3500863. DOI: 10.1242/jcs.111195

6 Hayward DG and Fry AM: NEK2 kinase in chromosome instability and cancer. Cancer Lett 237: 155-166, 2006. PMID: 16084011. DOI: 10.1016/j.canlet.2005.06.017.

7 Marina $M$ and Saavedra HI: NEK2 and PLK4: prognostic markers, drivers of breast tumorigenesis and drug resistance. Front Biosci 19: 352-365, 2014. PMID: 24389189.

8 Lin S, Zhou S, Jiang S, Liu X, Wang Y, Zheng X, Zhou H, Li X and Cai X: NEK2 regulates stem-like properties and predicts poor prognosis in hepatocellular carcinoma. Oncol Rep 36: 853862, 2016. PMID: 27349376. DOI: 10.3892/or.2016.4896.

9 Schultz SJ, Fry AM, Sutterlin C, Ried T and Nigg EA: Cell cycle-dependent expression of NEK2, a novel human protein kinase related to the NIMA mitotic regulator of Aspergillus nidulans. Cell Growth Differ 5: 625-635, 1994. PMID: 7522034.

10 O'Regan L, Blot J and Fry AM: Mitotic regulation by NIMArelated kinases. Cell Div 2: 25, 2007. PMID: 2018689. DOI: 10.1186/1747-1028-2-25

11 Fry AM, Arnaud L and Nigg EA: Activity of the human centrosomal kinase, NEK2, depends on an unusual leucine zipper dimerization motif. J Biol Chem 274: 16304-16310, 1999. PMID:10347187.

12 Rellos P, Ivins FJ, Baxter JE, Pike A, Nott TJ, Parkinson DM, Das S, Howell S, Fedorov O, Shen QY, Fry AM, Knapp S and Smerdon SJ: Structure and regulation of the human NEK2 centrosomal kinase. J Biol Chem 282: 6833-6842, 2007. PMID: 17197699. DOI: $10.1074 /$ jbc.M609721200

13 Uto K, Nakajo N and Sagata N: Two structural variants of NEK2 kinase, termed NEK2A and NEK2B, are differentially expressed in Xenopus tissues and development. Dev Biol 208: 456-464, 1999. PMID: 10191058. DOI: 10.1006/dbio.1999.9231

$14 \mathrm{Wu}$ W, Baxter JE, Wattam SL, Hayward DG, Fardilha M, Knebel A, Ford EM, da Cruz e Silva EF and Fry AM: Alternative splicing controls nuclear translocation of the cell cycle-regulated NEK2 kinase. J Biol Chem 282: 26431-26440, 2007. PMID: 17626005. DOI: 10.1074/jbc.M704969200

15 Hames RS, Wattam SL, Yamano H, Bacchieri R and Fry AM: APC/C-mediated destruction of the centrosomal kinase NEK2A occurs in early mitosis and depends upon a cyclin A-type D-box. EMBO J 20: 7117-7127, 2001. PMID: 125337. DOI: 10.1093/emboj/20.24.7117

16 Pfleger CM and Kirschner MW: The KEN box: An APC recognition signal distinct from the D box targeted by $\mathrm{CDH} 1$. Genes Dev 14: 655-665, 2000. PMID: 10733526.

17 Yao J, Fu C, Ding X, Guo Z, Zenreski A, Chen Y, Ahmed K, Liao J, Dou Z and Yao X: NEK2A kinase regulates the localization of numatrin to centrosome in mitosis. FEBS Lett 575: 112-118, 2004. PMID: 15388344. DOI: 10.1016/j.febslet. 2004.08.047 
18 Uto K and Sagata N: NEK2B, a novel maternal form of NEK2 kinase, is essential for the assembly or maintenance of centrosomes in early Xenopus embryos. EMBO J 19: 18161826, 2000. PMID: 302008. DOI: 10.1093/emboj/19.8.1816

19 Fletcher L, Cerniglia GJ, Yen TJ and Muschel RJ: Live cell imaging reveals distinct roles in cell cycle regulation for NEK2A and NEK2B. Biochim Biophys Acta 1744: 89-92, 2005. PMID: 15950749. DOI: 10.1016/j.bbamcr.2005.01.007

20 Liu Z, Wang Y, Wang S, Zhang J, Zhang F and Niu Y: NEK2C functions as a tumor promoter in human breast tumorigenesis. Int J Mol Med 30: 775-782, 2012. PMID: 22824957. DOI: 10.3892/ijmm.2012.1069

21 Wai DH, Schaefer KL, Schramm A, Korsching E, Van Valen F, Ozaki T, Boecker W, Schweigerer L, Dockhorn-Dworniczak B and Poremba C: Expression analysis of pediatric solid tumor cell lines using oligonucleotide microarrays. Int J Oncol 20: 441-451, 2002. PMID: 11836553.

22 Kokuryo T, Senga T, Yokoyama Y, Nagino M, Nimura Y and Hamaguchi M: NEK2 as an effective target for inhibition of tumorigenic growth and peritoneal dissemination of cholangiocarcinoma. Cancer Res 67: 9637-9642, 2007. PMID: 17942892. DOI: 10.1158/0008-5472.CAN-07-1489

23 Tsunoda N, Kokuryo T, Oda K, Senga T, Yokoyama Y, Nagino M, Nimura $\mathrm{Y}$ and Hamaguchi M: NEK2 as a novel molecular target for the treatment of breast carcinoma. Cancer Sci 100: 111-116, 2009. PMID: 19038001. DOI: 10.1111/j.1349-7006.2008.01007.x

24 Hayward DG, Clarke RB, Faragher AJ, Pillai MR, Hagan IM and Fry AM: The centrosomal kinase NEK2 displays elevated levels of protein expression in human breast cancer. Cancer Res 64: 7370-7376, 2004. PMID: 15492258. DOI: 10.1158/00085472.CAN-04-0960

25 Kim S, Lee K, Choi JH, Ringstad N and Dynlacht BD: NEK2 activation of KIF24 ensures cilium disassembly during the cell cycle. Nat Commun 6: 8087, 2015. PMID: 4545512. DOI: $10.1038 /$ ncomms 9087

26 van Roosmalen W, Le Devedec SE, Golani O, Smid M, Pulyakhina I, Timmermans AM, Look MP, Zi D, Pont C, de Graauw M, Naffar-Abu-Amara S, Kirsanova C, Rustici G, Hoen PA, Martens JW, Foekens JA, Geiger B and van de Water B: Tumor cell migration screen identifies SRPK1 as breast cancer metastasis determinant. J Clin Invest 125: 1648-1664, 2015. PMID: 4396474. DOI: 10.1172/JCI74440

27 Naro C, Barbagallo F, Chieffi P, Bourgeois CF, Paronetto MP and Sette C: The centrosomal kinase NEK2 is a novel splicing factor kinase involved in cell survival. Nucleic Acids Res 42: 3218-3227, 2014. PMID: 3950702. DOI: 10.1093/nar/gkt1307

28 Cappello P, Blaser H, Gorrini C, Lin DC, Elia AJ, Wakeham A, Haider S, Boutros PC, Mason JM, Miller NA, Youngson B, Done SJ and Mak TW: Role of NEK2 on centrosome duplication and aneuploidy in breast cancer cells. Oncogene 33: 2375-2384, 2014. PMID: 23708664. DOI: 10.1038/onc.2013.183

29 Komatsu M, Yoshimaru T, Matsuo T, Kiyotani K, Miyoshi Y, Tanahashi T, Rokutan K, Yamaguchi R, Saito A, Imoto S, Miyano S, Nakamura Y, Sasa M, Shimada M and Katagiri T: Molecular features of triple-negative breast cancer cells by genome-wide gene expression profiling analysis. Int J Oncol 42: 478-506, 2013. PMID: 23254957. DOI: 10.3892/ijo.2012.1744

30 Wang S, Li W, Lv S, Wang Y, Liu Z, Zhang J, Liu T and Niu Y: Abnormal expression of NEK2 and beta-catenin in breast carcinoma: Clinicopathological correlations. Histopathology 59:
631-642, 2011. PMID: 22014044. DOI: 10.1111/j.13652559.2011.03941.x

31 Wang S, Li W, Liu N, Zhang F, Liu H, Liu F, Liu J, Zhang T and Niu Y: NEK2A contributes to tumorigenic growth and possibly functions as potential therapeutic target for human breast cancer. J Cell Biochem 113: 1904-1914, 2012. PMID: 22234886. DOI: $10.1002 /$ jcb.24059

32 Suzuki K, Kokuryo T, Senga T, Yokoyama Y, Nagino M and Hamaguchi M: Novel combination treatment for colorectal cancer using NEK2 siRNA and cisplatin. Cancer Sci 101: 1163-1169, 2010. PMID: 20345485. DOI: 10.1111/j.1349-7006.2010. 01504.x

$33 \mathrm{Lu} \mathrm{L}$, Zhai X and Yuan R: Clinical significance and prognostic value of NEK2 protein expression in colon cancer. Int J Clin Exp Pathol 8: 15467-15473, 2015. PMID: 4713702.

34 Takahashi Y, Iwaya T, Sawada G, Kurashige J, Matsumura T, Uchi R, Ueo H, Takano Y, Eguchi H, Sudo T, Sugimachi K, Yamamoto H, Doki Y, Mori M and Mimori K: Up-regulation of NEK2 by microRNA-128 methylation is associated with poor prognosis in colorectal cancer. Ann Surg Oncol 21: 205-212, 2014. PMID: 24046120. DOI: 10.1245/s10434-013-3264-3

35 Neal CP, Fry AM, Moreman C, McGregor A, Garcea G, Berry DP and Manson MM: Overexpression of the NEK2 kinase in colorectal cancer correlates with beta-catenin relocalization and shortened cancer-specific survival. J Surg Oncol 110: 828-838, 2014. PMID: 25043295. DOI: 10.1002/jso.23717

36 Kokuryo T, Hibino S, Suzuki K, Watanabe K, Yokoyama Y, Nagino M, Senga $\mathrm{T}$ and Hamaguchi M: NEK2 siRNA therapy using a portal venous port-catheter system for liver metastasis in pancreatic cancer. Cancer Sci 107: 1315-1320, 2016. PMID: 27316377. DOI: $10.1111 /$ cas.12993

37 Ning Z, Wang A, Liang J, Liu J, Zhou T, Yan Q and Wang Z: Abnormal expression of NEK2 in pancreatic ductal adenocarcinoma: A novel marker for prognosis. Int J Clin Exp Pathol 7: 2462-2469, 2014. PMID: 4069945.

38 Chieffi P: Recent advances in molecular and cell biology of testicular germ-cell tumors. Int Rev Cell Mol Biol 312: 79-100, 2014. PMID: 25262239. DOI: 10.1016/B978-0-12-8001783.00003-8

39 Barbagallo F, Paronetto MP, Franco R, Chieffi P, Dolci S, Fry $\mathrm{AM}$, Geremia R and Sette C: Increased expression and nuclear localization of the centrosomal kinase NEK2 in human testicular seminomas. J Pathol 217: 431-441, 2009. PMID: 25262239. DOI: 10.1002 /path.2471

40 Zhang MX, Xu XM, Zhang P, Han NN, Deng JJ, Yu TT, Gan YY, He XQ and Long ZX: Effect of silencing NEK2 on biological behaviors of HepG2 in human hepatoma cells and MAPK signal pathway. Tumour Biol 37: 2023-2035, 2016. PMID: 26337275. DOI: 10.1007/s13277-015-3993-y

41 Wubetu GY, Morine Y, Teraoku H, Yoshikawa M, Ishikawa D, Yamada S, Ikemoto T, Saito YU, Imura S and Shimada M: High NEK2 Expression is a predictor of tumor recurrence in hepatocellular carcinoma patients after hepatectomy. Anticancer Res 36: 757-762, 2016. PMID: 26851035.

42 Zeng YR, Han ZD, Wang C, Cai C, Huang YQ, Luo HW, Liu ZZ, Zhuo YJ, Dai QS, Zhao HB, Liang YX and Zhong WD: Overexpression of NIMA-related kinase 2 is associated with progression and poor prognosis of prostate cancer. BMC Urol 15: 90, 2015. PMID: 4553013. DOI: 10.1186/s12894-015-0085-7

43 Zhong X, Guan X, Liu W and Zhang L: Aberrant expression of NEK2 and its clinical significance in non-small cell lung cancer. 
Oncol Lett 8: 1470-1476, 2014. PMID: 4156209. DOI: 10.3892 ol.2014.2396

44 Zhong X, Guan X, Dong Q, Yang S, Liu W and Zhang L: Examining NEK2 as a better proliferation marker in non-small cell lung cancer prognosis. Tumour Biol 35: 7155-7162, 2014. PMID: 24763826. DOI: 10.1007/s13277-014-1935-8

45 Landi MT, Dracheva T, Rotunno M, Figueroa JD, Liu H, Dasgupta A, Mann FE, Fukuoka J, Hames M, Bergen AW, Murphy SE, Yang P, Pesatori AC, Consonni D, Bertazzi PA, Wacholder S, Shih JH, Caporaso NE and Jen J: Gene expression signature of cigarette smoking and its role in lung adenocarcinoma development and survival. PLoS One 3: e1651, 2008. PMID: 2249927. DOI: 10.1371/journal.pone.0001651

46 Liu X, Gao Y, Lu Y, Zhang J, Li L and Yin F: Up-regulation of NEK2 is associated with drug resistance in ovarian cancer. Oncol Rep 31: 745-754, 2014. PMID: 24337664. DOI: 10.3892/ or.2013.2910

47 Arai E, Gotoh M, Tian Y, Sakamoto H, Ono M, Matsuda A, Takahashi Y, Miyata S, Totsuka H, Chiku S, Komiyama M, Fujimoto H, Matsumoto K, Yamada T, Yoshida T and Kanai Y: Alterations of the spindle checkpoint pathway in clinicopathologically aggressive $\mathrm{CpG}$ island methylator phenotype clear cell renal cell carcinomas. Int J Cancer 137: 2589-2606, 2015. PMID: 26061684. DOI: 10.1002/ijc.29630

48 Cheng Y, Hong M and Cheng B: Identified differently expressed genes in renal cell carcinoma by using multiple microarray datasets running head: differently expressed genes in renal cell carcinoma. Eur Rev Med Pharmacol Sci 18: 1033-1040, 2014. PMID: 24763884.

$49 \mathrm{Gu} \mathrm{C}$, Yang Y, Sompallae R, Xu H, Tompkins VS, Holman C, Hose D, Goldschmidt H, Tricot G, Zhan F and Janz S: FOXM1 is a therapeutic target for high-risk multiple myeloma. Leukemia 30: 873-882, 2015. PMID: 26648534. DOI: 10.1038/leu.2015.334

50 Stricker TP, Henriksen KJ, Tonsgard JH, Montag AG, Krausz $\mathrm{TN}$ and Pytel P: Expression profiling of 519 kinase genes in matched malignant peripheral nerve sheath tumor/plexiform neurofibroma samples is discriminatory and identifies mitotic regulators $B U B 1 B, P B K$ and $N E K 2$ as overexpressed with transformation. Mod Pathol 26: 930-943, 2013. PMID: 23370767. DOI: $10.1038 /$ modpathol.2012.242

51 Andreasson U, Dictor M, Jerkeman M, Berglund M, Sundstrom C, Linderoth J, Rosenquist R, Borrebaeck CA and Ek S: Identification of molecular targets associated with transformed diffuse large B-cell lymphoma using highly purified tumor cells Am J Hematol 84: 803-808, 2009. PMID: 19844990. DOI: 10.1002/ajh.21549

52 de Vos S, Hofmann WK, Grogan TM, Krug U, Schrage M, Miller TP, Braun JG, Wachsman W, Koeffler HP and Said JW: Gene expression profile of serial samples of transformed B-cell lymphomas. Lab Invest 83: 271-285, 2003. PMID: 12594241.

53 Fry AM, Mayor T, Meraldi P, Stierhof YD, Tanaka K and Nigg EA: C-NAP1, a novel centrosomal coiled-coil protein and candidate substrate of the cell cycle-regulated protein kinase Nek2. J Cell Biol 141: 1563-1574, 1998. PMID: 2133000.

54 Zhou W, Yang Y, Xia J, Wang H, Salama ME, Xiong W, Xu H, Shetty S, Chen T, Zeng Z, Shi L, Zangari M, Miles R, Bearss D, Tricot $G$ and Zhan F: NEK2 induces drug resistance mainly through activation of efflux drug pumps and is associated with poor prognosis in myeloma and other cancers. Cancer Cell 23: 48-62, 2013. PMID: 23328480. DOI: 10.1016/j.ccr.2012.12.001
55 Xia J, Franqui Machin R, Gu Z and Zhan F: Role of NEK2A in human cancer and its therapeutic potentials. Biomed Res Int 2015: 862461, 2015. PMID: 4330945. DOI: 10.1155/2015/ 862461

56 Takata O, Kawamura YJ, Konishi F, Sasaki J, Kai T, Miyakura $\mathrm{Y}$, Nagai $\mathrm{H}$ and Tsukamoto $\mathrm{T}$ : cDNA array analysis for prediction of hepatic metastasis of colorectal carcinoma. Surg Today 36: 608-614, 2006. PMID: 16794795. DOI: 10.1007/ s00595-006-3210-0

57 Benvenuti S and Comoglio PM: The MET receptor tyrosine kinase in invasion and metastasis. J Cell Physiol 213: 316-325, 2007. PMID: 17607709 . DOI: $10.1002 /$ jcp. 21183

58 Boccaccio C and Comoglio PM: Invasive growth: A MET-driven genetic programme for cancer and stem cells. Nat Rev Cancer 6: 637-645, 2006. PMID: 16862193. DOI: 10.1038/nrc 1912

59 Das TK, Dana D, Paroly SS, Perumal SK, Singh S, Jhun H, Pendse J, Cagan RL, Talele TT and Kumar S: Centrosomal kinase NEK2 cooperates with oncogenic pathways to promote metastasis. Oncogenesis 2: e69, 2013. PMID: 3816224. DOI: 10.1038/oncsis.2013.34

60 Lee J and Gollahon L: NEK2-targeted ASO or siRNA pretreatment enhances anticancer drug sensitivity in triplenegative breast cancer cells. Int J Oncol 42: 839-847, 2013. PMID: 3597451. DOI: 10.3892/ijo.2013.1788

61 Yang Y, Zhou W, Xia J, Gu Z, Wendlandt E, Zhan X, Janz S, Tricot $G$ and Zhan F: NEK2 mediates ALDH1A1-dependent drug resistance in multiple myeloma. Oncotarget 5: 1198611997, 2014. PMID: 4322982.

62 Meng L, Carpenter K, Mollard A, Vankayalapati H, Warner SL, Sharma S, Tricot G, Zhan F and Bearss DJ: Inhibition of NEK2 by small molecules affects proteasome activity. Biomed Res Int 2014: 273180, 2014. PMID: 4182079. DOI: 10.1155/2014/273180

63 Wen S, Liu Y, Yang M, Yang K, Huang J and Feng D: Increased NEK2 in hepatocellular carcinoma promotes cancer progression and drug resistance by promoting PP1/Akt and Wnt activation. Oncol Rep 36: 2193-2199, 2016. PMID: 27509921. DOI: 10.3892/or.2016.5009

64 Huang LY, Chang CC, Lee YS, Huang JJ, Chuang SH, Chang JM, Kao KJ, Lau GM, Tsai PY, Liu CW, Lin HS, Gish RG and Lau JY: Inhibition of HEC1 as a novel approach for treatment of primary liver cancer. Cancer Chemother Pharmacol 74: 511520, 2014. PMID: 25038613. DOI: 10.1007/s00280-014-2540-7

65 Huang LY, Chang CC, Lee YS, Chang JM, Huang JJ, Chuang SH, Kao KJ, Lau GM, Tsai PY, Liu CW, Lin HS and Lau JY: Activity of a novel HEC1-targeted anticancer compound against breast cancer cell lines in vitro and in vivo. Mol Cancer Ther 13: 1419-1430, 2014. PMID: 24694948. DOI: 10.1158/15357163.MCT-13-0700

66 Huang LY, Lee YS, Huang JJ, Chang CC, Chang JM, Chuang SH, Kao KJ, Tsai YJ, Tsai PY, Liu CW, Lin HS and Lau JY: Characterization of the biological activity of a potent small molecule HEC1 inhibitor TAI-1. J Exp Clin Cancer Res 33: 6, 2014. PMID: 24401611. DOI: $10.1186 / 1756-9966-33-6$

67 Fang Y and Zhang X: Targeting NEK2 as a promising therapeutic approach for cancer treatment. Cell Cycle 15: 895-907, 2016. PMID: 27019372. DOI: 10.1080/15384101.2016.1152430

68 Frett B, Brown RV, Ma M, Hu W, Han H and Li HY: Therapeutic melting pot of never in mitosis gene A-related kinase 2 (NEK2): a perspective on NEK2 as an oncology target and recent advancements in NEK2 small molecule inhibition. J Med Chem 57: 5835-5844, 2014. PMID: 24517277. DOI: 10.1021/jm401719n 
69 Henise JC and Taunton J: Irreversible NEK2 kinase inhibitors with cellular activity. J Med Chem 54: 4133-4146, 2011. PMID: 3663048. DOI: $10.1021 / \mathrm{jm} 200222 \mathrm{~m}$

70 Chen Y, Riley DJ, Zheng L, Chen PL and Lee WH: Phosphorylation of the mitotic regulator protein HEC1 by NEK2 kinase is essential for faithful chromosome segregation. J Biol Chem 277: 49408-49416, 2002. PMID: 12386167. DOI: 10.1074/jbc.M207069200

71 Lee YS, Chuang SH, Huang LY, Lai CL, Lin YH, Yang JY, Liu CW, Yang SC, Lin HS, Chang CC, Lai JY, Jian PS, Lam K, Chang JM, Lau JY and Huang JJ: Discovery of 4-aryl-Narylcarbonyl-2-aminothiazoles as HEC1/NEK2 inhibitors. Part I: Optimization of in vitro potencies and pharmacokinetic properties. J Med Chem 57: 4098-4110, 2014. PMID: 24773549. DOI: $10.1021 / \mathrm{jm} 401990 \mathrm{~s}$

72 Qiu XL, Li G, Wu G, Zhu J, Zhou L, Chen PL, Chamberlin AR and Lee WH: Synthesis and biological evaluation of a series of novel inhibitor of NEK2/HEC1 analogues. J Med Chem 52: 1757-1767, 2009. PMID: 2670097. DOI: 10.1021/jm8015969

73 Wu G, Qiu XL, Zhou L, Zhu J, Chamberlin R, Lau J, Chen PL and Lee WH: Small molecule targeting the HEC1/NEK2 mitotic pathway suppresses tumor cell growth in culture and in animal. Cancer Res 68: 8393-8399, 2008. PMID: 2709694. DOI: 10.1158/0008-5472.CAN-08-1915

$74 \mathrm{Hu}$ CM, Zhu J, Guo XE, Chen W, Qiu XL, Ngo B, Chien R, Wang YV, Tsai CY, Wu G, Kim Y, Lopez R, Chamberlin AR, Lee EY and Lee WH: Novel small molecules disrupting HEC1/NEK2 interaction ablate tumor progression by triggering NEK2 degradation through a death-trap mechanism. Oncogene 34: 1220-1230, 2015. PMID: 4175300. DOI: 10.1038/onc.2014.67
75 Innocenti P, Cheung KM, Solanki S, Mas-Droux C, Rowan F, Yeoh S, Boxall K, Westlake M, Pickard L, Hardy T, Baxter JE, Aherne GW, Bayliss R, Fry AM and Hoelder S: Design of potent and selective hybrid inhibitors of the mitotic kinase NEK2: Structure-activity relationship, structural biology, and cellular activity. J Med Chem 55: 3228-3241, 2012. PMID: 22404346. DOI: $10.1021 / \mathrm{jm} 201683 \mathrm{~b}$

76 Hayward DG, Newbatt Y, Pickard L, Byrne E, Mao G, Burns S, Sahota NK, Workman P, Collins I, Aherne W and Fry AM: Identification by high-throughput screening of viridin analogs as biochemical and cell-based inhibitors of the cell cycle-regulated NEK2 kinase. J Biomol Screen 15: 918-927, 2010. PMID: 20664067. DOI: $10.1177 / 1087057110376537$

77 Fraser MM, Watson PM, Fraig MM, Kelley JR, Nelson PS, Boylan AM, Cole DJ and Watson DK: CaSm-mediated cellular transformation is associated with altered gene expression and messenger RNA stability. Cancer Res 65: 6228-6236, 2005. PMID: 16024624. DOI: 10.1158/0008-5472.CAN-05-0650

78 Mowa MB, Crowther C and Arbuthnot P: Therapeutic potential of adenoviral vectors for delivery of expressed RNAi activators. Expert Opin Drug Deliv 7: 1373-1385, 2010. PMID: 21073358. DOI: $10.1517 / 17425247.2010 .533655$

Received January 24, 2019

Revised March 27, 2019

Accepted April 2, 2019 